Subscriber access provided by Caltech Library

\title{
Article
}

\section{Growth kinetics and size distribution dynamics of viscous secondary organic aerosol}

Rahul A. Zaveri, John E. Shilling, Alla Zelenyuk, Jiumeng Liu, David M. Bell, Emma L. D'Ambro, Cassandra J. Gaston, Joel A. Thornton, Alexander Laskin, Peng Lin, Jacqueline M Wilson, Richard C. Easter, Jian Wang, Allan K. Bertram, Scot T. Martin, John H. Seinfeld, and Douglas R. Worsnop

Environ. Sci. Technol., Just Accepted Manuscript • DOI: 10.1021/acs.est.7b04623 • Publication Date (Web): 15 Dec 2017

Downloaded from http://pubs.acs.org on December 18, 2017

\section{Just Accepted}

"Just Accepted" manuscripts have been peer-reviewed and accepted for publication. They are posted online prior to technical editing, formatting for publication and author proofing. The American Chemical Society provides "Just Accepted" as a free service to the research community to expedite the dissemination of scientific material as soon as possible after acceptance. "Just Accepted" manuscripts appear in full in PDF format accompanied by an HTML abstract. "Just Accepted" manuscripts have been fully peer reviewed, but should not be considered the official version of record. They are accessible to all readers and citable by the Digital Object Identifier (DOI®). "Just Accepted" is an optional service offered to authors. Therefore, the "Just Accepted" Web site may not include all articles that will be published in the journal. After a manuscript is technically edited and formatted, it will be removed from the "Just Accepted" Web site and published as an ASAP article. Note that technical editing may introduce minor changes to the manuscript text and/or graphics which could affect content, and all legal disclaimers and ethical guidelines that apply to the journal pertain. ACS cannot be held responsible for errors or consequences arising from the use of information contained in these "Just Accepted" manuscripts. 


\section{Growth kinetics and size distribution dynamics of}

\section{viscous secondary organic aerosol}

Rahul A. Zaveri ${ }^{1 *}$, John E. Shilling ${ }^{1}$, Alla Zelenyuk ${ }^{2}$, Jiumeng Liu ${ }^{1}$, David M. Bell ${ }^{2,}$, Emma L.

$D^{\prime} A m b r 0^{3,4}$, Cassandra J. Gaston ${ }^{3,+}$, Joel A. Thornton ${ }^{3,4}$, Alexander Laskin ${ }^{5,7}$, Peng Lin ${ }^{5,7}$, Jacqueline Wilson ${ }^{2}$, Richard C. Easter ${ }^{1}$, Jian Wang ${ }^{6}$, Allan K. Bertram ${ }^{7}$, Scot T. Martin ${ }^{8,9}$, John H. Seinfeld ${ }^{10,11}$, and Douglas R. Worsnop ${ }^{12}$

${ }^{1}$ Atmospheric Sciences and Global Change Division, Pacific Northwest National Laboratory, Richland, WA 99352, USA

${ }^{2}$ Physical Sciences Division, Pacific Northwest National Laboratory, Richland, WA 99352, USA

${ }^{3}$ Department of Atmospheric Sciences, University of Washington, Seattle, WA 98195, USA

${ }^{4}$ Department of Chemistry, University of Washington, Seattle, WA 98195, USA

${ }^{5}$ William R. Wiley Environmental Molecular Sciences Laboratory, Pacific Northwest National Laboratory, Richland, WA 99352, USA

${ }^{6}$ Environmental and Climate Sciences Department, Brookhaven National Laboratory, Upton, NY 11973, USA

${ }^{7}$ Department of Chemistry, University of British Columbia, Vancouver, BC V6T 1Z1, Canada

${ }^{8}$ John A. Paulson School of Engineering and Applied Sciences, Harvard University, Cambridge, MA 02138, USA

${ }^{9}$ Department of Earth and Planetary Sciences, Harvard University, Cambridge, MA 02138, USA

${ }^{10}$ Division of Chemistry and Chemical Engineering, California Institute of Technology, Pasadena, CA 91125, USA

${ }^{11}$ Division of Engineering and Applied Science, California Institute of Technology, Pasadena, CA 91125, USA

${ }^{12}$ Center for Aerosol and Cloud Chemistry, Aerodyne Research, Billerica, MA 01821, USA

KEYWORDS: Biogenic secondary organic aerosol, gas-particle partitioning, aerosol dynamics, semisolid phase state, viscosity, bulk diffusivity 
1 ABSTRACT: Low bulk diffusivity inside viscous semisolid atmospheric secondary organic aerosol

2 (SOA) can prolong equilibration timescale, but its broader impacts on aerosol growth and size

3 distribution dynamics are poorly understood. Here we present quantitative insights into the

4 effects of bulk diffusivity on the growth and evaporation kinetics of SOA formed under dry

5 conditions from photooxidation of isoprene in the presence of a bimodal aerosol consisting of

6 Aitken (ammonium sulfate) and accumulation (isoprene or $\alpha$-pinene SOA) mode particles.

7 Aerosol composition measurements and evaporation kinetics indicate that isoprene SOA is

8 composed of several semivolatile organic compounds (SVOCs), with some reversibly reacting to

9 form oligomers. Model analysis shows that liquid-like bulk diffusivities can be used to fit the

10 observed evaporation kinetics of accumulation mode particles, but fail to explain the growth

11 kinetics of bimodal aerosol by significantly under-predicting the evolution of the Aitken mode.

12 In contrast, the semisolid scenario successfully reproduces both evaporation and growth

13 kinetics, with the interpretation that hindered partitioning of SVOCs into large viscous particles

14 effectively promotes the growth of smaller particles that have shorter diffusion timescales. This

15 effect has important implications for the growth of atmospheric ultrafine particles to

16 climatically-active sizes. 


\section{TOC/ABSTRACT ART}

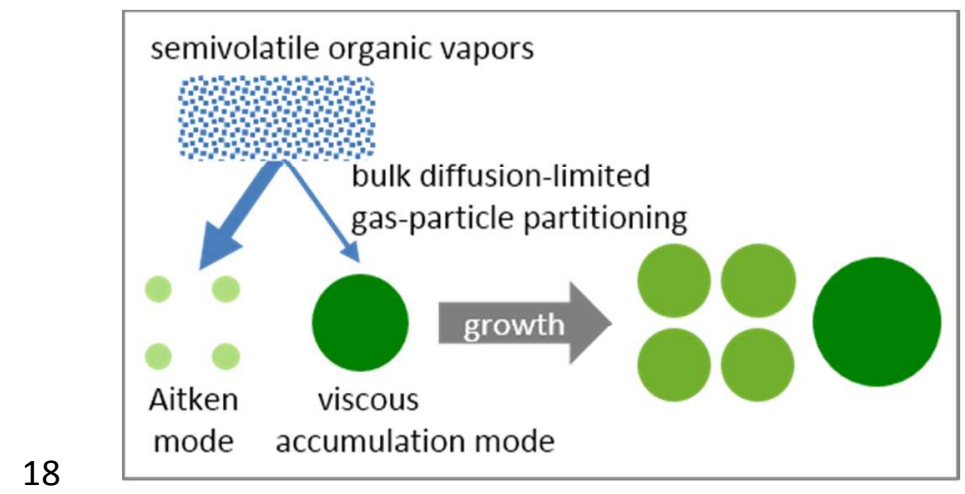




\section{INTRODUCTION} 37 radiative effects ${ }^{9}$.

38

39

Secondary organic aerosol (SOA), produced by oxidation of anthropogenic and biogenic volatile organic compounds (VOC), constitutes a major fraction of the submicron atmospheric aerosol ${ }^{1}$, and plays a crucial role in the growth of nanoparticles to climatically active sizes of about $80 \mathrm{~nm}$ and higher ${ }^{2-4}$. The current understanding is that, in the absence of an appreciable particulate aqueous phase, SOA formation and particle growth mechanisms depend strongly on the volatility (i.e., effective saturation vapor pressure, $\mathrm{C}^{*}$ ) of the oxidation products, and broadly fall into two categories: (1) kinetic condensation of extremely low-volatility compounds ${ }^{5}$ (C* $<3$ $\times 10^{-4} \mathrm{gg} \mathrm{m}^{-3}$ ) and supersaturated vapors to the pre-existing Fuchs-corrected surface area size distribution, facilitating the growth of the smallest particles ${ }^{3,6}$; and (2) Raoult's law-based equilibrium absorptive partitioning of semivolatile organic compounds (SVOC, $0.3<C^{*}<300 \mu \mathrm{g}$ $\mathrm{m}^{-3}$ ) to the pre-existing organic mass size distribution ${ }^{7}$, favoring the growth of larger particles ${ }^{3,6}$. The latter assumes that the absorbing particulate organic phase is liquid-like, implying rapid intra-particle diffusion of the condensing compounds (i.e., bulk diffusivity, $D_{b}>10^{-10} \mathrm{~cm}^{2} \mathrm{~s}^{-1}$ ). Most atmospheric chemical transport models currently assume liquid organic particles with either rapid or instantaneous equilibration of SVOCs ${ }^{8}$. The use of the mass-based equilibrium versus the kinetic approach to partition all of the SOA formed in an atmospheric model can dramatically alter the aerosol size distribution and have a large impact on the simulated aerosol

However, the physicochemical processes governing SOA formation are more complex than currently represented in atmospheric models ${ }^{10}$. For instance, SOA formation can occur via absorption of SVOCs into pre-existing aerosol, followed by rapid particle-phase reactions to 
41 form nonvolatile products ${ }^{11,12}$. A rapid particle-phase reaction effectively lowers the

42 concentration of the condensing SVOC at the particle surface, and its effect is reflected in the

43 evolution of the SOA size distribution ${ }^{12,13}$. In the case of an instantaneous particle-phase

44 reaction, the surface concentration of the condensing compound becomes zero, and the

45 resulting size distribution evolution is identical to that seen in kinetic condensation of

46 nonvolatile compounds ${ }^{14}$. Relatively slower particle-phase accretion reactions of some SVOCs

47 or "monomers" also produce significant amounts of effectively nonvolatile oligomers with large

48 molecular weights ${ }^{15-20}$. These oligomers are thought to be responsible for increasing the

49 viscosity of SOA particles, making them glassy or semisolid under dry to moderate relative

50 humidity $(\mathrm{RH})$, gradually transitioning to a liquid-like state at higher $\mathrm{RH}^{19-27}$. Low bulk diffusivity

$51\left(D_{b}<10^{-13} \mathrm{~cm}^{2} \mathrm{~s}^{-1}\right)$ inside viscous semisolid particles can slow down evaporation of SVOCs ${ }^{28-31}$,

52 inhibit gas-particle partitioning of SVOCs, prolong equilibration timescales ${ }^{14,32,33}$, and affect

53 chemical reactivity ${ }^{34-37}$. While increase in $\mathrm{RH}$ affects evaporation ${ }^{38-40}$ and inter-particle mixing

54 processes $^{41}$ in some SOA systems, broader implications of low $D_{b}$ on growth and size

55 distribution dynamics of viscous SOA are poorly understood.

56 Here we report results from a laboratory chamber investigation of growth and evaporation

57 kinetics of SOA formed from photooxidation of isoprene-the most abundantly emitted non-

58 methane biogenic VOC on Earth ${ }^{42}$. Our experimental strategy consisted of a bimodal aerosol

59 used as seeds upon which isoprene SOA was formed. SOA volatility was estimated from

60 evaporation kinetics of size-selected particles at room temperature in a separate chamber ${ }^{28,38}$.

61 The role of bulk diffusion in modulating gas-particle partitioning was then assessed through a 
62 model closure of the evaporation and growth kinetics, with compositional constraints provided

63 by particle-phase organic speciation measurements.

64

65

66

67

68

\section{EXPERIMENTAL SECTION}

Growth Experiments. Two aerosol growth kinetics experiments were conducted under dry (RH 10\%) and low- $\mathrm{NO}_{\mathrm{x}}$ conditions in $10.6 \mathrm{~m}^{3}$ FEP Teflon environmental chamber at Pacific Northwest National Laboratory ${ }^{43}$ (Figure S1). The chamber was continually flushed with purified air prior to the start of each experiment until particle number concentrations $<10 \mathrm{~cm}^{-3}$ were observed with a Scanning Mobility Particle Sizer (SMPS). The experiments were run in the batch mode where reactants were added to the chamber in discrete quantities.

Each experiment consisted of two stages. In Stage 1 of Experiment 1, isoprene was injected to the chamber either by evaporating a measured quantity of liquid under a stream of pure air or through addition of metered volumes from a calibrated cylinder. Hydrogen peroxide $(50 \%$, Aldrich) was evaporated into the chamber by gently warming the liquid under a flow of pure air and served as an $\mathrm{OH}$ radical precursor. Chamber $\mathrm{RH}$ was measured with a Rotronics sensor (SC05) located inside the chamber. Aitken mode ammonium sulfate (AS) seed particles (dry diameter, $D_{p} \sim 50 \mathrm{~nm}$ ) were injected into the chamber by atomizing, drying, and size-selecting them with a DMA (TSI, 3080L). Photochemistry was initiated by turning on 104 UV-blacklights (Q-labs, UV-340) symmetrically surrounding the chamber that produced a stable UV flux equivalent to a photolysis rate of $\mathrm{J}_{\mathrm{NO} 2}=0.2 \mathrm{~min}^{-1}$ and $\mathrm{J}_{\mathrm{H} 2 \mathrm{O} 2} \sim 2.8 \times 10^{-3} \mathrm{~min}^{-1}$. $\mathrm{NO}_{2}$ photolysis rate was determined using two methods-the photochemical stationary state method ${ }^{44}$ and by direct measurement using a $\mathrm{J}_{\mathrm{NO} 2}$ radiometer ${ }^{45}$. The two measurements are in agreement. The $\mathrm{H}_{2} \mathrm{O}_{2}$ photolysis rate was determined by tuning a simple model to generate the concentrations of $\mathrm{OH}$ needed to explain 
84 the observed isoprene decay rate. Multiple aliquots of the reactants were added and allowed to

85

86

87 react to condense SOA on the AS seed particles and grow them to $>200 \mathrm{~nm}$ (accumulation mode). The UV lights were then turned off and Aitken mode AS seed $\left(D_{p} \sim 40 \mathrm{~nm}\right)$ particles were then injected into the chamber to prepare the bimodal aerosol. Then in Stage 2 of the experiment, the UV lights were turned on to form additional isoprene SOA on the pre-existing bimodal aerosol. At the end of Stage 1 and Stage 2, size-selected samples of the accumulation mode SOA particles, respectively denoted as "P1" and "P2", were transferred into separate small chambers to study their evaporation kinetics under dry conditions $(\mathrm{RH}<5 \%)$ and at room temperature.

Experiment 2 was conducted in same manner as Experiment 1, except that the accumulation mode seed SOA (in Stage 1) was formed from photooxidation of $\alpha$-pinene (instead of isoprene). The UV lights were turned off after $\alpha$-pinene was almost completely consumed toward the end of Stage 1 , followed by injection of isoprene and Aitken mode AS seed ( $\left.D_{p} \sim 40 \mathrm{~nm}\right)$ into the chamber. Then in Stage 2, the UV lights were again turned on to form additional isoprene SOA on the pre-existing bimodal aerosol. The time evolution of key variables in Experiments 1 and 2 are illustrated in Figures S2 and S3, respectively.

Isoprene and $\alpha$-pinene mixing ratio and some of their oxidation products were measured online (i.e., in real time) with a Proton Transfer Reaction Mass Spectrometer ${ }^{46}$ (PTR-MS; lonicon HS). The PTR-MS was regularly calibrated during the experimental work using a cylinder of known gas concentrations. Particle size distributions were measured continuously using an SMPS (TSI, 3936). The SMPS data were recorded with a time resolution of $5 \mathrm{~min}$, and the instrument was set to measure particles in the range $14-710 \mathrm{~nm}$ mobility diameter divided into 110 
106 logarithmically distributed size bins. Data were processed with standard TSI software including

107 a correction for multiple-charged particles.

108 Aerosol composition was continuously measured with an Aerodyne High Resolution Time-of-

109 Flight Aerosol Mass Spectrometer ${ }^{47,48}$ (HR-ToF-AMS). AMS data were processed using standard

110 techniques described in the literature and regularly calibrated through the laboratory

111 campaign $^{49}$. Volume measurements from the SMPS and that derived from the AMS

112 measurements agreed to within the measurement uncertainty. The SOA mass concentrations

113 reported here were calculated from SMPS volume, using a density of $1.4 \mathrm{~g} \mathrm{~cm}^{-3}$ for SOA

114 (measured by miniSPLAT) and $1.77 \mathrm{~g} \mathrm{~cm}^{-3}$ for the ammonium sulfate core.

115 A suite of oxygenated products in the particle-phase were analyzed in Experiment 1 with a high-

116 resolution time of flight chemical ionization mass spectrometer (HR-ToF-CIMS) using iodide

117 adduct ionization as described previously ${ }^{50-52}$, coupled to a Filter Inlet for Gases and AEROsols ${ }^{51}$

118 (FIGAERO). FIGAERO samples were timed to approximately coincide with the samples P1 and

119 P2. After a particle collection period, the filter was heated at a rate of 10 or $15^{\circ} \mathrm{C} \min ^{-1}$ to 200

$120{ }^{\circ} \mathrm{C}$ for a temperature-programed thermal desorption and then kept at $200{ }^{\circ} \mathrm{C}$ for the remainder

121 of the desorption time (40 min total desorption time). A more detailed description of FIGAERO

122 and HR-ToF-CIMS is given in the Supporting Information.

123 At the end of the Experiment 1, an aerosol sample taken from the environmental chamber was

124 collected onto the Teflon filter for offline analysis. The SOA sample was probed directly from

125 the filter using a custom-built Nanospray Desorption Electrospray Ionization (Nano-DESI) source

126 coupled to a high resolution LTQ-Orbitrap mass spectrometer ${ }^{53,54}$ (Thermo Electron, Bremen, 
127 Germany). A more detailed description of Nano-DESI-HRMS is given in the Supporting 128 Information.

129 Evaporation Experiments. The particle samples P1 and P2 (collected during Experiment 1) were 130 size-selected with a differential mobility analyzer (DMA, TSI Inc., Model 3081) and passed 131 through two charcoal denuders (TSI Inc., Model 3062) connected in series and kept at room 132 temperature to remove gas-phase organics. Particles with a narrow distribution of mobility 133 diameters and low number concentrations $\left(\sim 100 \mathrm{~cm}^{-3}\right)$ were loaded into one of the evaporation 134 chambers (volumes of 7,11 , or $13 \mathrm{~L}$ ) that were partially filled with activated charcoal to 135 continuously remove the evaporated organics ${ }^{28}$. The evaporation chambers were operated at 136 room temperature and $\mathrm{RH}<5 \%$.

137 Typical duration of the evaporation experiments was $\sim 24$ hours during which particle vacuum 138 aerodynamic diameter $\left(D_{\text {va }}\right)$, shape, density, and composition were periodically measured using 139 single particle mass spectrometer, $\operatorname{miniSPLA}^{55}$ (a detailed description is given in the Supporting 140 Information). Particle evaporation kinetics was thus quantified by measuring changes in $D_{\text {va }}$, 141 with $0.5 \%$ precision. Since the spherical SOA-containing particles did not change their shape 142 during evaporation process, and the density of SOA increased only by $<2 \%$ during early stages 143 of evaporation and remained constant thereafter, the observed changes in $D_{\text {va }}$ can be directly 144 related to changes in volume fraction of organics, taking into account the contribution of AS 145 seeds. While the particle number concentration in the evaporation chamber decreased due to 146 wall losses and continual sampling, these losses had no effect on the evaporation rates, which 147 were determined from the measured changes in particles $D_{v a}$. 
148 Box Models. A multi-layer particle box model was used to interpret evaporation kinetics. The model divides a single spherical particle into 200 concentric layers and explicitly simulates mass

150 transfer of multiple compounds from the particle by taking into account compound volatility

$151\left(C^{*}\right)$, gas-phase diffusivity $\left(D_{g}\right)$, interfacial mass accommodation $(\alpha)$, intra-particle bulk 152 diffusivity $\left(D_{b}\right)$, and reversible particle-phase reactions ${ }^{14}$.

153 The sectional aerosol box model MOSAIC (Model for Simulating Aerosol Interactions and 154 Chemistry $)^{14,56}$ was used to interpret the observed bimodal aerosol growth kinetics. MOSAIC 155 dynamically partitions multiple compounds to all particle size bins by taking into account 156 compound volatility, gas-phase diffusion, interfacial mass accommodation, intra-particle bulk 157 diffusion, and reversible particle-phase reactions. The thermodynamic driving force for mass 158 transfer is governed by Raoult's law; bulk diffusion is treated using the two-film theory. More 159 detailed descriptions of the multi-layer model and MOSAIC are given in the Supporting 160 Information.

\section{RESULTS AND DISCUSSION}

162 Figure 1 shows the observed time evolutions of aerosol number and volume size distributions 163 to illustrate the growth kinetics of the bimodal aerosol due to isoprene SOA formation during 164 Stage 2 of Experiments 1 and 2. In terms of mode diameters, the $\sim 40 \mathrm{~nm}$ Aitken mode rapidly 165 grew to about $100 \mathrm{~nm}$ or more while the accumulation mode experienced relatively modest 166 growth. Table S1 summarizes the mode diameters and SOA mass concentrations in the two 167 modes at the beginning of Stage 1 (initial) and after $\Delta t=60 \mathrm{~min}$ (Experiment 1) and $32 \mathrm{~min}$ 
168 (Experiment 2) of growth. Our objective is to unravel the physicochemical mechanisms 169 governing the growth kinetics of the two modes in both experiments.

170 Multigenerational photooxidation of isoprene forms many products, but their yields, volatilities,

171 and SOA formation mechanisms are uncertain. Under dry and low- $\mathrm{NO}_{\mathbf{x}}$ conditions, as is the case

172 here, isoprene photooxidation can form isoprene dihydroxydihydroperoxide $\left(\mathrm{C}_{5} \mathrm{H}_{12} \mathrm{O}_{6}\right)$ and

173 related species that lead to SOA formation ${ }^{45,52,57}$. Since growth kinetics crucially depends on the

174 volatility of the condensing compounds as well as their particle-phase diffusivity and

175 reactivity ${ }^{12,14}$, we first interpreted the evaporation kinetics to estimate these quantities, and

176 then used them to constrain the interpretation of the growth kinetics.

177 Interpreting Evaporation Kinetics. A multi-layer particle model was used to simulate the 178 evaporation of size-selected accumulation mode isoprene SOA samples P1 (initial) and P2 (after 179 growth) obtained in Experiment 1. FIGAERO thermograms showed that about 50-60\% of

180 isoprene SOA mass was composed of $\mathrm{C}_{5} \mathrm{H}_{12} \mathrm{O}_{5}$ and $\mathrm{C}_{5} \mathrm{H}_{12} \mathrm{O}_{6}$ while the remaining $40-50 \%$ mass

181 consisted of several compounds that desorbed at unexpectedly high temperatures and were 182 inferred as thermal fragmentation products of oligomers ${ }^{52}$ (Figures $2 \mathrm{a}$ and $2 \mathrm{~b}$ ). The total SOA 183 mass estimated from the sum of individual FIGAERO thermograms was in excellent agreement 184 (within $\sim 4 \%$ difference) with that calculated using SMPS volume. Additionally, offline Nano185 DESI-HRMS analysis of isoprene SOA sample qualitatively confirmed the presence of $\mathrm{C}_{5} \mathrm{H}_{12} \mathrm{O}_{5}$ 186 and $\mathrm{C}_{5} \mathrm{H}_{12} \mathrm{O}_{6}$ as major products mixed with several different oligomers (Figure $2 \mathrm{c}$ ). The particle-

187 phase O:C ratio for isoprene SOA, as determined from the HR-ToF-AMS measurements, 188 remained at $\sim 0.9$ throughout Stages 1 and 2. 
189 The compositions of SOA samples P1 and P2 are summarized in Figure 3a. As shown in Figures

$1903 \mathrm{c}$ and $3 \mathrm{~d}$, more than $90 \%$ of isoprene SOA evaporated over a period of about $25-28 \mathrm{~h}$. This

191 suggests that the oligomers slowly decomposed at room temperature to form semi-volatile

192 monomers that subsequently evaporated from the particles ${ }^{58}$. Furthermore, the distinctly

193 different rates of evaporation over the first $5 \mathrm{~h}$ and the subsequent $15-20 \mathrm{~h}$ periods suggest the

194 presence of at least two types of oligomers with different decomposition timescales. The

195 complex mixture of oligomers was represented in the model by two surrogate nonvolatile

196 dimers - Dimer 1 and Dimer 2 , each reversibly formed from respective surrogate monomers -

$197 \mathrm{SVOC}_{1}$ and $\mathrm{SVOC}_{2}$, with the same formation rate constant $\left(\mathrm{k}_{\mathrm{f}}\right)$ but different decomposition

198 constants $\left(k_{d, 1}\right.$ and $\left.k_{d, 2}\right)$ :

$199 \mathrm{SVOC}_{1}+\mathrm{SVOC}_{1} \underset{k_{d, 1}}{\stackrel{k_{f}}{\rightleftarrows}}$ Dimer $_{1}$, and

$200 \mathrm{SVOC}_{2}+\mathrm{SVOC}_{2} \underset{k_{d, 2}}{\stackrel{k_{f}}{\rightleftarrows}}$ Dimer $_{2}$

201 Since evaporating monomers could not be explicitly identified from FIGAERO thermograms,

202 both $\mathrm{SVOC}_{1}$ and $\mathrm{SVOC}_{2}$ were assumed to have molecular weights of $136 \mathrm{~g} \mathrm{~mol}^{-1}$ and their

203 corresponding dimers were assumed to have molecular weights of $272 \mathrm{~g} \mathrm{~mol}^{-1}$. The dimer-

204 monomer pairs were assumed to be at equilibrium and uniformly distributed in the particle's

205 organic phase at the start of the evaporation experiment. Mass accommodation coefficients $(\alpha)$

206 of all the evaporating compounds were assumed at 0.1. The bulk gas-phase concentrations

207 were assumed at zero as the particle evaporated. 
208 The multi-layer model was manually iterated to determine the volatility $\left(C^{*}\right)$ of the four compounds $\left(\mathrm{C}_{5} \mathrm{H}_{12} \mathrm{O}_{5}, \mathrm{C}_{5} \mathrm{H}_{12} \mathrm{O}_{6}, \mathrm{SVOC}_{1}, \mathrm{SVOC}_{2}\right)$ for different values of $\mathrm{D}_{\mathrm{b}}, \mathrm{k}_{\mathrm{f}}, \mathrm{k}_{\mathrm{d}, 1}$, and $\mathrm{k}_{\mathrm{d}, 2}$ that reproduced the observed evaporation kinetics. Although this problem has multiple solutions

211 due to lack of enough independent constraints, the plausible solutions (i.e., those that take into

212 account reversible oligomer formation) required all four evaporating species to be semivolatile

213 (i.e., $C^{*}>0.3 \mu \mathrm{g} \mathrm{m}{ }^{-3}$ ). A set of rate constants values of $k_{f}=3 \times 10^{-6} \mathrm{~m}^{3} \mathrm{~mol}^{-1} \mathrm{~s}^{-1}, \mathrm{k}_{\mathrm{d}, 1}=5 \times 10^{-4} \mathrm{~s}^{-1}$

214 and $\mathrm{k}_{\mathrm{d}, 2}=1.4 \times 10^{-5} \mathrm{~s}^{-1}$ was determined such that the pseudo-first order forward reaction

215 timescales of $\mathrm{SVOC}_{1}$ and $\mathrm{SVOC}_{2}$ at equilibrium were respectively about 10 and $30 \mathrm{~min}$. The

216 room temperature decomposition timescales of Dimer $_{1}$ and Dimer $_{2}$ were respectively about 30

217 and $1000 \mathrm{~min}$, such that the dimers constituted the dominant fraction at equilibrium. Upon

218 heating the SOA samples at the rate of $10-15^{\circ} \mathrm{C} \mathrm{min}-1$ to $200{ }^{\circ} \mathrm{C}$, FIGAERO detected small, high

219 volatility compounds during desorption, suggesting they are likely fragmentation products of

220 oligomers ${ }^{59-61}$ as opposed to decomposition of oligomers to monomers. The FIGAERO

221 thermograms support the long decomposition timescales estimated here for the two dimers,

222 such that they would largely fragment before decomposing back to monomers during

223 temperature-programmed thermal desorption. Using the same set of values for the rate

224 constants, it was possible to obtain different sets of $C^{*}$ values as a function of $D_{b}$ that

225 reproduced the observed evaporation kinetics. The same value of $D_{b}$ was assumed for all four

226 compounds and was held constant throughout the simulation.

227 Figure $3 \mathrm{~b}$ shows two sets of $\mathrm{C}^{*}$ values for: (i) high bulk diffusivity values representing the

228 "liquid-like scenario" $\left(D_{b}>10^{-10} \mathrm{~cm}^{2} \mathrm{~s}^{-1}\right)$, and (ii) a low bulk diffusivity value representing the

229 "semisolid scenario" $\left(D_{b}=2 \times 10^{-15} \mathrm{~cm}^{2} \mathrm{~s}^{-1}\right)$. The $D_{b}$ value in semisolid scenario is consistent with 
230 the low end of the range recently estimated for isoprene SOA under dry conditions, based on

231 the Stokes-Einstein relation between viscosity and diffusivity ${ }^{25}$. In both scenarios, the $\mathrm{C}^{*}$ of

$232 \mathrm{C}_{5} \mathrm{H}_{12} \mathrm{O}_{5}$ and $\mathrm{C}_{5} \mathrm{H}_{12} \mathrm{O}_{6}$ were $\sim 1-2 \mu \mathrm{g} \mathrm{m}^{-3}$, consistent with the $0.5-2 \mu \mathrm{g} \mathrm{m}^{-3}$ range independently

233 estimated from FIGAERO thermograms ${ }^{52}$. The $C^{*}$ of $\mathrm{SVOC}_{1}$ and $\mathrm{SVOC}_{2}$ were 30 and $3 \mu \mathrm{g} \mathrm{m} \mathrm{m}^{-3}$ in

234 the liquid-like scenario, while they were both $30 \mu \mathrm{g} \mathrm{m}^{-3}$ in the semisolid scenario. The predicted

235 evaporation curves for the liquid-like and semisolid scenarios are shown in Figures 3c and 3d,

236 respectively. The evaporation profiles of individual compounds are shown in Figure S4. Similar

237 sets of $C^{*}$ values can be obtained by varying $D_{b}, k_{f}, k_{d, 1}$, and $k_{d, 2}$. In general, the fitted $C^{*}$ values

238 of all compounds tended to increase (or remained constant) with decreasing $D_{b}$. The fitted C*

239 values of $\mathrm{C}_{5} \mathrm{H}_{12} \mathrm{O}_{5}$ and $\mathrm{C}_{5} \mathrm{H}_{12} \mathrm{O}_{6}$ were insensitive to variation in $\mathrm{k}_{\mathrm{f}}, \mathrm{k}_{\mathrm{d}, 1}$, and $\mathrm{k}_{\mathrm{d}, 2}$ while the fitted

$240 \mathrm{C}^{*}$ values of $\mathrm{SVOC}_{1}$ and $\mathrm{SVOC}_{2}$ decreased with increasing values of these rate constants. It was

241 also possible to reproduce evaporation kinetics by ignoring oligomer formation and instead

242 simply assuming that the evaporating compounds do not chemically react within liquid-like

243 particles. In this scenario (not shown in Figure 3), the fitted $C^{*}$ values for $\mathrm{C}_{5} \mathrm{H}_{12} \mathrm{O}_{5}, \mathrm{C}_{5} \mathrm{H}_{12} \mathrm{O}_{6}$,

$244 \mathrm{SVOC}_{1}, \mathrm{SVOC}_{2}$ were $1.1,1.1,10,0.05 \mu \mathrm{g} \mathrm{m}{ }^{-3}$, respectively. Here, $\mathrm{SVOC}_{2}$ is a low volatility

245 compound instead of semivolatile, and this scenario is referred to as "low-volatility scenario".

246 The question is which or any of these estimated sets of $C^{*}$ values can also explain the observed

247 growth kinetics, with the implicit assumption that the compounds inferred from evaporation

248 kinetics are the same as those that condensed from the gas phase to form the SOA.

249 Interpreting Growth Kinetics. Figure 4 shows the growth of the bimodal aerosol during Stage 2

250 of Experiment 1. Over a period of $60 \mathrm{~min}$, the $\sim 40 \mathrm{~nm}$ Aitken mode grew to $82 \mathrm{~nm}$ while the

$251209 \mathrm{~nm}$ accumulation mode grew to $217 \mathrm{~nm}$. In terms of the newly added SOA mass, the Aitken 
252 and accumulation modes grew by $0.45 \mu \mathrm{g} \mathrm{m}^{-3}$ and $1.48 \mu \mathrm{g} \mathrm{m} \mathrm{m}^{-3}$, respectively, after correcting for 253 particle wall loss. We used the sectional aerosol box-model MOSAIC to simulate the effects of 254 volatility and bulk diffusivity on the growth kinetics of these two modes. Isoprene mixing ratio 255 and aerosol size distribution in the model were initialized using observations at the beginning of 256 Stage 2. The compositions of the Aitken and accumulation modes were initialized to ammonium 257 sulfate and that estimated for the P1 sample (with a $50 \mathrm{~nm}$ ammonium sulfate core), 258 respectively. The $\mathrm{OH}$ radical concentration in the model was tuned to reproduce the observed 259 decay of isoprene in the chamber. Although it takes several steps to produce condensable 260 oxidation products from isoprene photooxidation, the isoprene $+\mathrm{OH}$ reaction in the model was 261 parameterized to directly form $\mathrm{C}_{5} \mathrm{H}_{12} \mathrm{O}_{5}, \mathrm{C}_{5} \mathrm{H}_{12} \mathrm{O}_{6}, \mathrm{SVOC}_{1}$, and $\mathrm{SVOC}_{2}$. The gas-phase yields of 262 these four compounds were then adjusted such that the final bulk SOA composition predicted 263 by the model matched that of the P2 sample, while the total amount of SOA formed in the 264 model was constrained to the wall-loss corrected value of $1.93 \mu \mathrm{g} \mathrm{m}^{-3}$ observed after $60 \mathrm{~min}$. 265 This modeling approach effectively circumvents the uncertainties associated with gas-phase 266 multigenerational photochemistry of isoprene and the yields of condensable oxidation 267 products, their volatilities, and vapor wall losses. The simulation period $(\Delta t)$ was limited to 60 268 min so that particle wall loss could be neglected in the model calculations.

269 The two sets of $C^{*}$ values shown in Figure $3 \mathrm{~b}$ were used to simulate the growth kinetics for the 270 liquid-like and semisolid scenarios. And as done previously, the same set of values for $k_{f}, k_{d, 1}$, 271 and $k_{d, 2}$ was used for both scenarios. In the liquid-like scenario, the growth predictions were 272 essentially insensitive to $D_{b}>10^{-10} \mathrm{~cm}^{2} \mathrm{~s}^{-1}$. In the semisolid scenario, the Aitken and 273 accumulation modes were allowed to take different values of $D_{b}$, but the prescribed value in 
274 each mode was held constant throughout the simulation for simplicity. We did not attempt to

275 parameterize $D_{b}$ as a function of composition in this study due to the large uncertainty

276 associated with this parameter. Finally, we also simulated the growth kinetics by assuming that

277 SOA was entirely formed from condensation of a single nonvolatile vapor. This scenario, which

278 is referred to as the "nonvolatile scenario," represents the extreme version of the low-volatility

279 scenario discussed in section 3.1. Two simulations were carried out with mass accommodation

280 coefficient value for the nonvolatile vapor of $\alpha=0.1$ and $\alpha=1$. Although clearly implausible in

281 the light of evaporation data, the two nonvolatile scenarios examine the extreme sensitivity of

282 the predicted aerosol growth kinetics to the volatility and mass accommodation coefficient of

283 the condensing vapor. Lastly, aerosol growth kinetics due to instantaneous particle-phase

284 chemical reaction of a semivolatile vapor is identical to that from condensation of a nonvolatile

285 vapor. Thus, the nonvolatile scenarios also examine the extreme sensitivity of the predicted

286 growth kinetics to the rate constant of the reactive semivolatile vapors that form oligomers.

287 Figure 4 shows that the liquid-like scenario appears to reproduce the size of the accumulation

288 mode particles, but severely under-predicted the growth of the Aitken mode. By neglecting

289 bulk diffusion limitation, the liquid-like scenario tends to partition the condensing semivolatile

290 organic vapors according to the pre-existing organic mass size distribution. As a result, the

291 liquid-like scenario partitioned $1.89 \mathrm{~g} \mathrm{~m}^{-3}$ (instead of observed $1.48 \mu \mathrm{g} \mathrm{m}^{-3}$ ) of the newly

292 formed SOA to the accumulation mode at the expense of the Aitken, which received just 0.04

$293 \mu \mathrm{g} \mathrm{m}^{-3}$ (instead of the observed $0.45 \mu \mathrm{g} \mathrm{m}^{-3}$ ). The nonvolatile scenarios with $\alpha=0.1$ and $\alpha=1$

294 were progressively better than the liquid-like scenario with respect to the predicted growth of

295 the Aitken mode, but still fell significantly short compared to the observed growth. A 
296 nonvolatile vapor or a highly reactive semivolatile vapor condenses according to the pre-

297 existing Fuchs-corrected surface area size distribution and thereby favors the growth of the

298 smallest particles. Thus, the nonvolatile scenario with $\alpha=1$ represents the maximum possible

299 growth of the Aitken mode within the conventional modeling framework, but it still failed to

300 explain the observations.

301 In contrast to the liquid-like and nonvolatile scenarios, the semisolid scenario was able to 302 reproduce the growths of both Aitken and accumulation modes when their $D_{b}$ values were set 303 to $2 \times 10^{-14}$ and $2 \times 10^{-15} \mathrm{~cm}^{2} \mathrm{~s}^{-1}$, respectively, with the latter being identical to that needed to 304 reproduce the evaporation kinetics of the accumulation mode SOA. An order of magnitude 305 larger value of $D_{b}$ required for the Aitken mode appears to be consistent with the relatively less 306 volatile $\mathrm{C}_{5} \mathrm{H}_{12} \mathrm{O}_{5}$ and $\mathrm{C}_{5} \mathrm{H}_{12} \mathrm{O}_{6}$ initiating a liquid-like organic phase in the Aitken mode that then 307 facilitated the absorption of more volatile vapors, which subsequently formed oligomers and 308 gradually increased the viscosity with aging ${ }^{28,30,62}$. In contrast, the pre-existing SOA in the 309 accumulation mode was relatively more aged, and hence more viscous, less volatile, and less 310 diffusive. The resulting hindered growth of the accumulation mode SOA thus promoted the 311 growth of the Aitken mode particles that were able to compete more effectively for the 312 condensing semivolatile vapors. Figure S5 illustrates the sensitivity of the predicted growth 313 kinetics to the prescribed $D_{b}$ values for each mode in Experiment 1, with the semisolid scenario $314 D_{b}$ values shown in Figure 4 as the base case. It can be seen that a higher than base case $D_{b}$ 315 value for the accumulation mode or a lower than base case $D_{b}$ value for the Aitken mode 316 appreciably slows down the growth of the Aitken mode. In contrast, a lower than base case $D_{b}$ 317 for the accumulation mode over predicts the growth of the Aitken mode. 
318 Similar results were obtained for Experiment 2 in which isoprene SOA was formed in the

319 presence of Aitken mode ammonium sulfate and accumulation mode $\alpha$-pinene SOA seed

320 particles. While $\alpha$-pinene SOA is expected to be composed of a mixture of several compounds

321 and oligomers, it was assumed in the model to be composed of a nonvolatile surrogate

322 compound with a molecular weight of $200 \mathrm{~g} \mathrm{~mol}^{-1}$ for the purpose of kinetically partitioning

323 isoprene SOA into it as governed by Raoult's law. As before, the isoprene mixing ratio and

324 aerosol size distribution in the model were initialized using observations at the beginning of

325 Stage 2. The same two sets $C^{*}$ values for the liquid-like and semisolid scenarios along with the

326 same set of values for $k_{f}, k_{d, 1}$, and $k_{d, 2}$ were used as previously employed for modeling

327 Experiment 1. Due to lack of FIGAERO-CIMS speciation measurements in Experiment 2, the gas-

328 phase yields of the four condensing compounds were adjusted to match the bulk composition

329 of sample P2 of Experiment 1 (shown in Figure 3a). The total amount of predicted isoprene SOA

330 was constrained to the wall-loss corrected observed value of $4.53 \mu \mathrm{g} \mathrm{m}^{-3}$ after 32 min into Stage

3312 of Experiment 2. As shown in Figure 5, the liquid-like and nonvolatile scenarios again under-

332 predicted the growth of the Aitken mode while the semisolid scenario was able to capture the

333 growths of both the Aitken and accumulation modes when their $D_{b}$ values were respectively set

334 to $2 \times 10^{-14}$ and $2 \times 10^{-15} \mathrm{~cm}^{2} \mathrm{~s}^{-1}$-the same as those used in modeling Experiment 1. In general,

$335 \alpha$-pinene SOA is expected to be more viscous than isoprene SOA ${ }^{25}$. However, large uncertainty

336 exists in the viscosity measurements for $\alpha$-pinene SOA under dry conditions ${ }^{25}$, with additional

337 uncertainty present in estimating $D_{b}$ values using Stokes-Einstein relationship. The identical $D_{b}$

338 values for isoprene and $\alpha$-pinene SOA needed in the present calculations is therefore likely

339 fortuitous, but nevertheless affirm the presence of appreciable particle-phase diffusion 
340 limitation in the aged accumulation mode SOA in both experiments. Figure S6 illustrates the

341 sensitivity of the predicted growth kinetics to the prescribed $D_{b}$ values for each mode in

342 Experiment 2, with the semisolid scenario $D_{b}$ values shown in Figure 5 as the base case. The

343 sensitivity results are similar to those discussed for Experiment 1.

344 Since any particle-phase diffusion limitation to condensing SVOCs should inhibit the growth of 345 both small and large particles, the enhanced growth of small particles resulting from diffusion-

346 limited growth may therefore seem counterintuitive. However, this is possible because the 347 intra-particle bulk diffusion timescales varies as $D_{p}^{2}$ while the particle mass varies as $D_{p}^{3}$. For

348 instance, organic particles with $D_{p}=20 \mathrm{~nm}$ and $200 \mathrm{~nm}$ respectively have bulk diffusion

349 timescales of about 1 and $100 \mathrm{~min}$ for the same value of $D_{b}=1 \times 10^{-15} \mathrm{~cm}^{2} \mathrm{~s}^{-1}$, but the amount 350 of mass needed to double the size of one hundred $20 \mathrm{~nm}$ particles is equivalent to growing a 351 single $200 \mathrm{~nm}$ particle to $240 \mathrm{~nm}$. Therefore, even modest hindrance in the uptake of SVOCs by 352 large semisolid particles allows the SVOCs to be available for absorption by ultrafine particles 353 that have lower diffusion limitations due to smaller size. If these SVOCs undergo particle-phase 354 reactions to form low volatility products, as is the case in the present study, then the small 355 particles will continue to absorb the SVOCs and grow at the expense of larger particles. 356 Although growth kinetics experiments need to be conducted as a function of $\mathrm{RH}$ and for other 357 SOA systems, current results demonstrate that hindered growth of large viscous organic 358 particles in the atmosphere can enhance the growth of co-existing ultrafine particles and 359 thereby affect the production of climatically-active particles under relatively dry conditions in 360 the mid-latitudes as well as under relatively cold conditions in the middle and upper 361 troposphere where organic particles likely exist in semisolid or solid phase state ${ }^{62}$. 

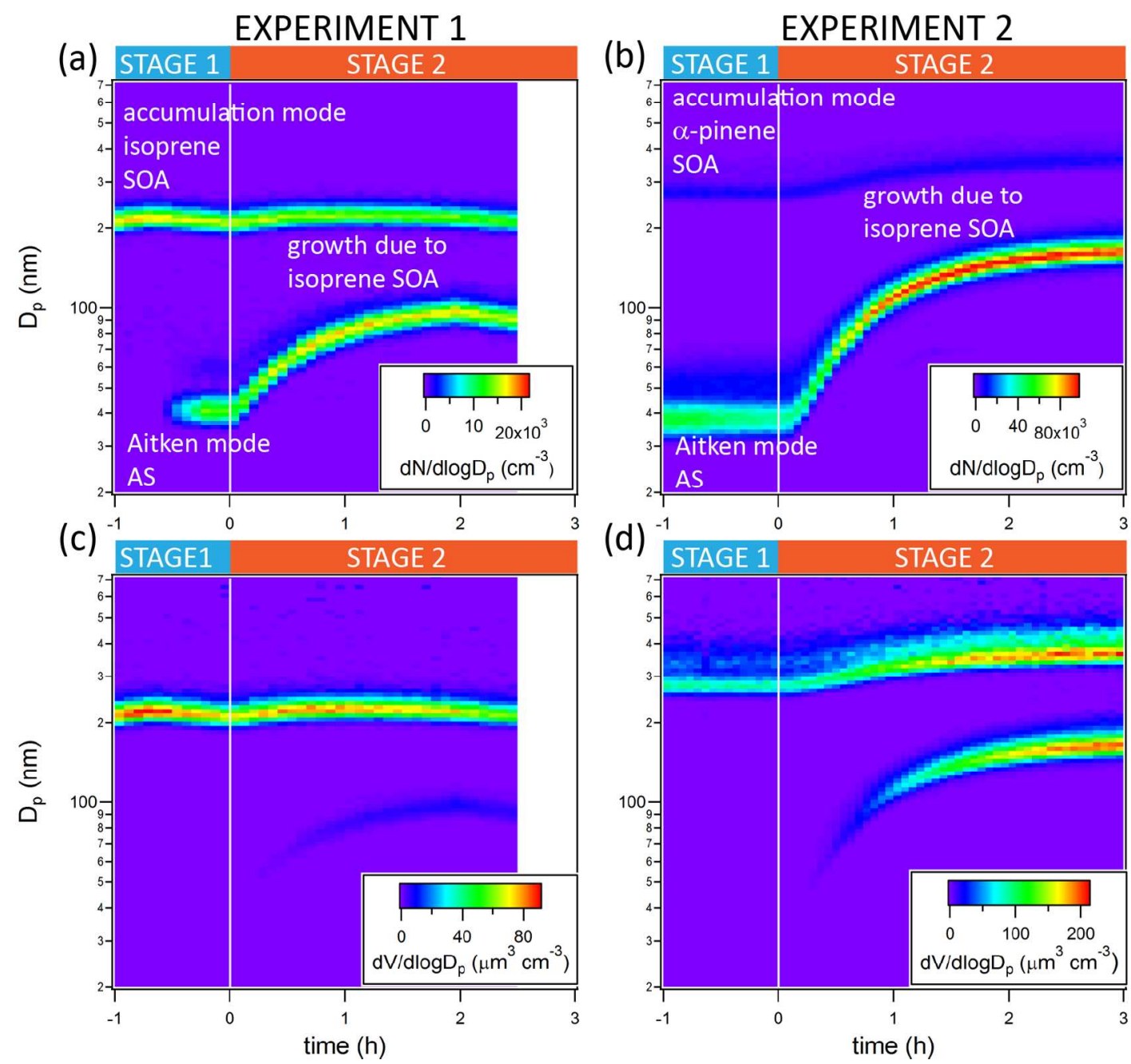

Figure 1. Observed time evolutions of $(a, b)$ aerosol number size distributions and $(c, d)$ aerosol volume size distributions in Experiments 1 and 2. The initial (Stage 1) bimodal aerosol in Experiment 1 consists of an Aitken mode composed of ammonium sulfate (AS) and an accumulation mode composed of isoprene SOA. The initial (Stage 1) bimodal aerosol in Experiment 2 consists of an Aitken mode composed of AS and an accumulation mode

371 composed of $\alpha$-pinene SOA. Growth of the bimodal aerosol in Stage 2 occurred due to isoprene 372 SOA formation in both experiments. 

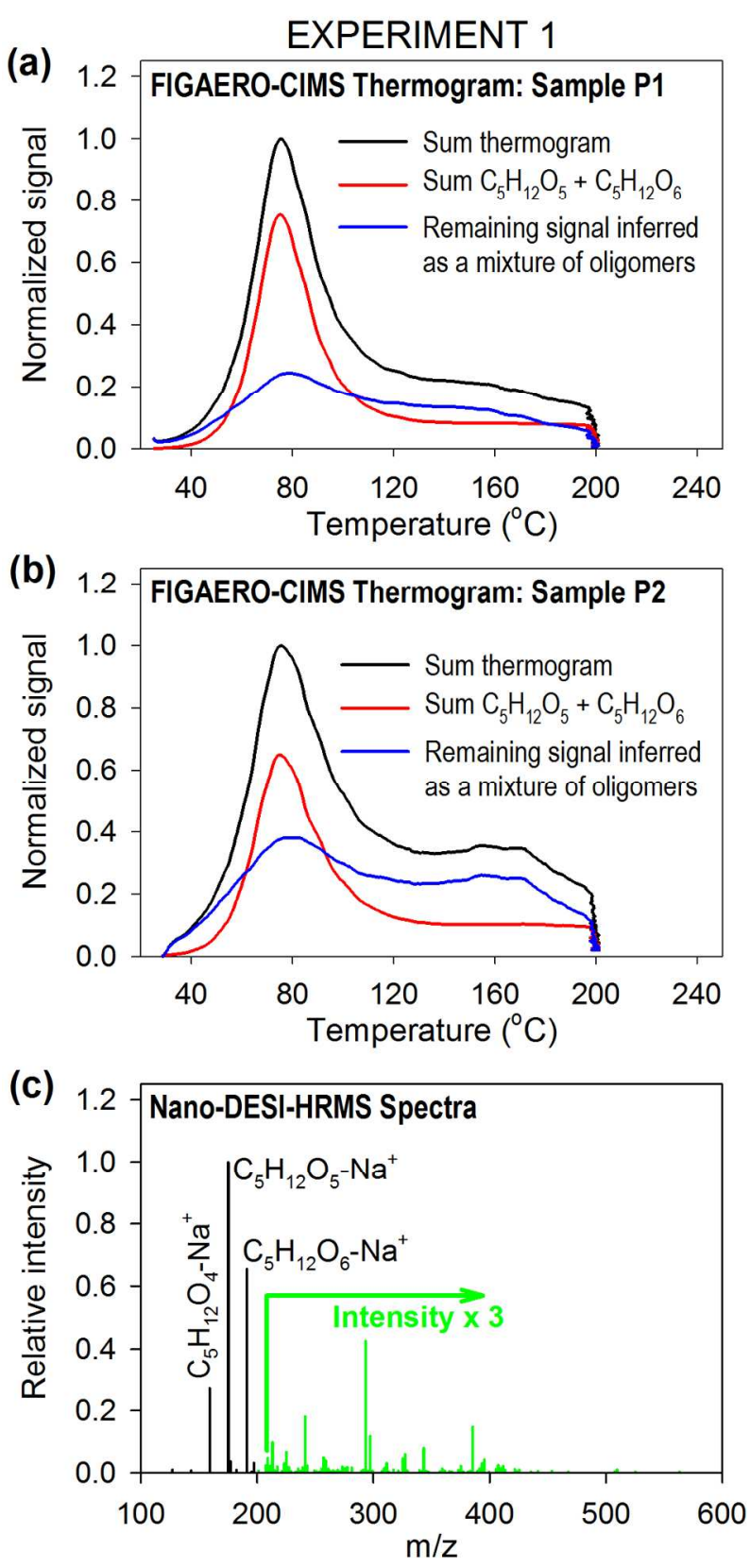

Figure 2. Chemical composition of isoprene SOA formed in Experiment 1. (a) FIGAERO HR-ToFCIMS thermograms for sample P1. The sum thermogram (black line) represents the sum signal of all compounds with formula $\mathrm{C}_{x} \mathrm{H}_{y} \mathrm{O}_{z} \mathrm{l}-$. The remainder of the signal is shown in blue. While the sum of $\mathrm{C}_{5} \mathrm{H}_{12} \mathrm{O}_{5}$ and $\mathrm{C}_{5} \mathrm{H}_{12} \mathrm{O}_{6}$ (red line) have a Gaussian-like shape with a defined $\mathrm{T}_{\max }$ at 75-78 ${ }^{\circ} \mathrm{C}$, the remaining signal (blue line) shows a broad desorption profile. The thermogram of the remaining signal shows that the material is resistant to evaporation and is inferred as a mixture of oligomers. (b) FIGAERO HR-ToF-CIMS thermograms for sample P2. (c) Nano-DESI-HRMS spectra of SOA sample collected at the end of the experiment, with the positive mode ions identified and assigned with $\mathrm{C}_{\mathrm{x}} \mathrm{H}_{\mathrm{y}} \mathrm{O}_{z}$ formulas. 


\section{EXPERIMENT 1: Evaporation Kinetics}
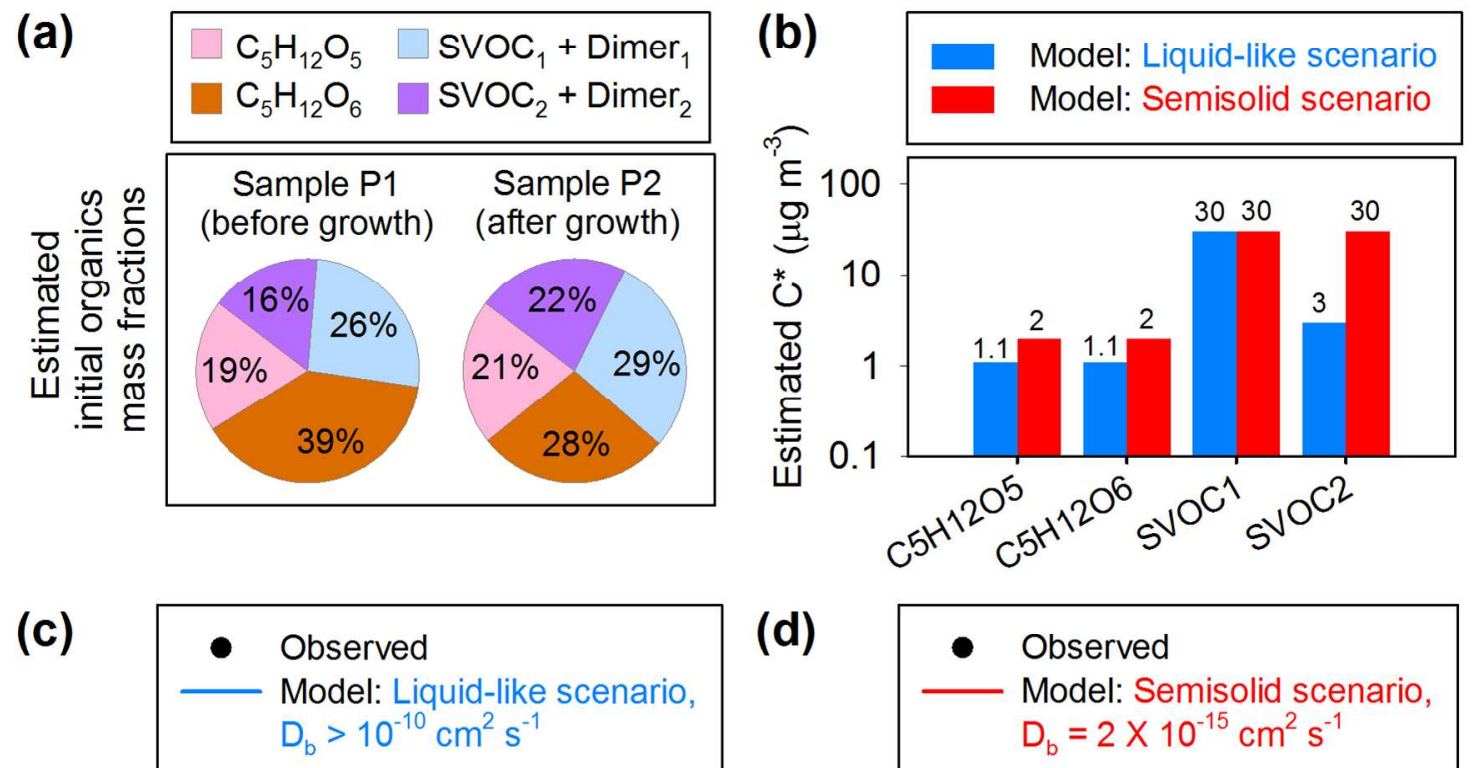

(d)
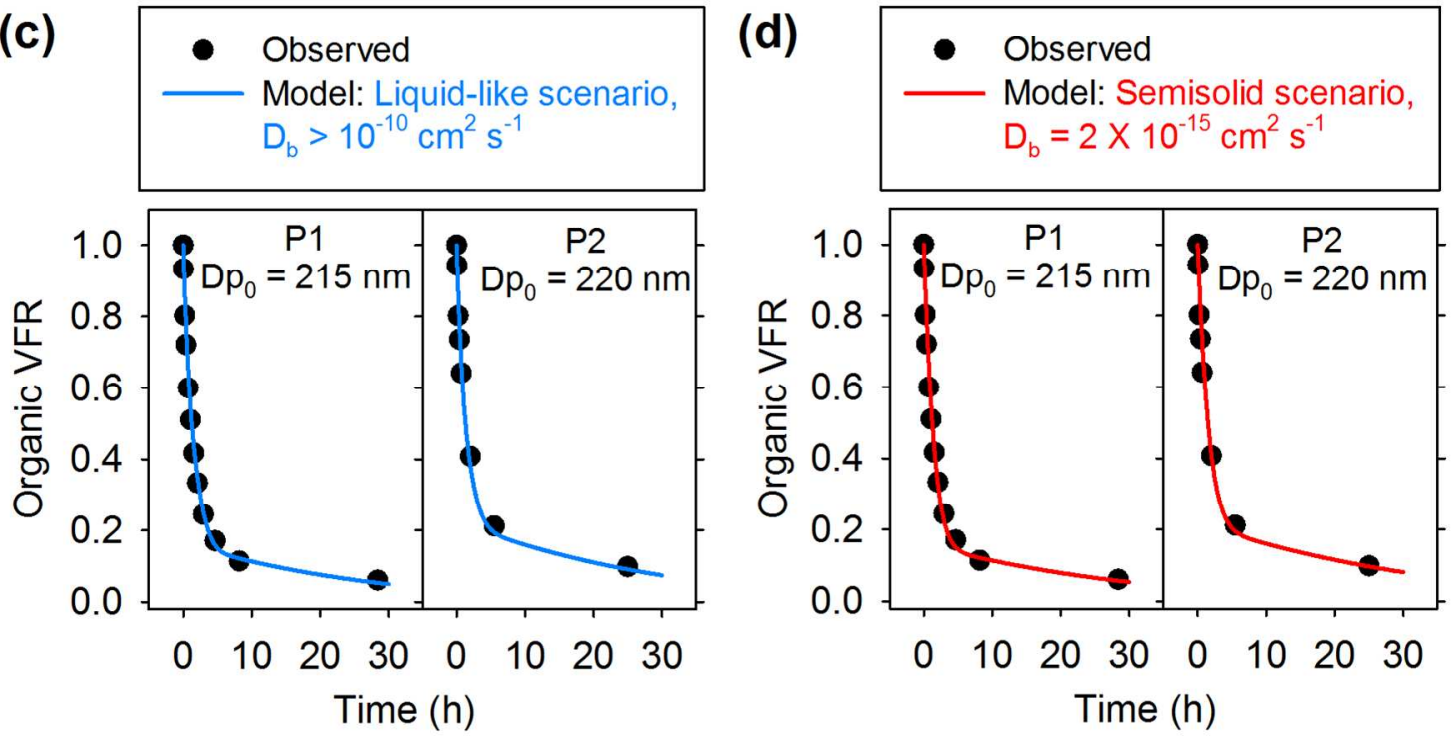

Figure 3. Evaporation kinetics of the large-mode isoprene SOA particles obtained in Experiment 1. (a) Estimated initial compositions of SOA in samples P1 and P2 (as indicated in Figure S2a) based on interpretation of FIGAERO-CIMS thermograms (Figure 2a). Sample P1 represents aged isoprene SOA formed during Stage 1 of the experiment and sample P2 represents its state after additional isoprene SOA formation in Stage 2. (b) Estimated volatilities ( $C^{*}$ ) of the four constituent compounds, with SOA modeled as liquid-like (with $D_{b}>10^{-10} \mathrm{~cm}^{2} \mathrm{~s}^{-1}$ ) and as semisolid (with $D_{b}=2 \times 10^{-15} \mathrm{~cm}^{2} \mathrm{~s}^{-1}$ ). Comparison of the observed organic volume fraction remaining (VFR) as a function of time for the P1 and P2 samples with that modeled as (c) liquidlike and (d) semisolid. The model was initialized using the estimated SOA compositions shown in (a) and the estimated species volatilities shown in (b). 


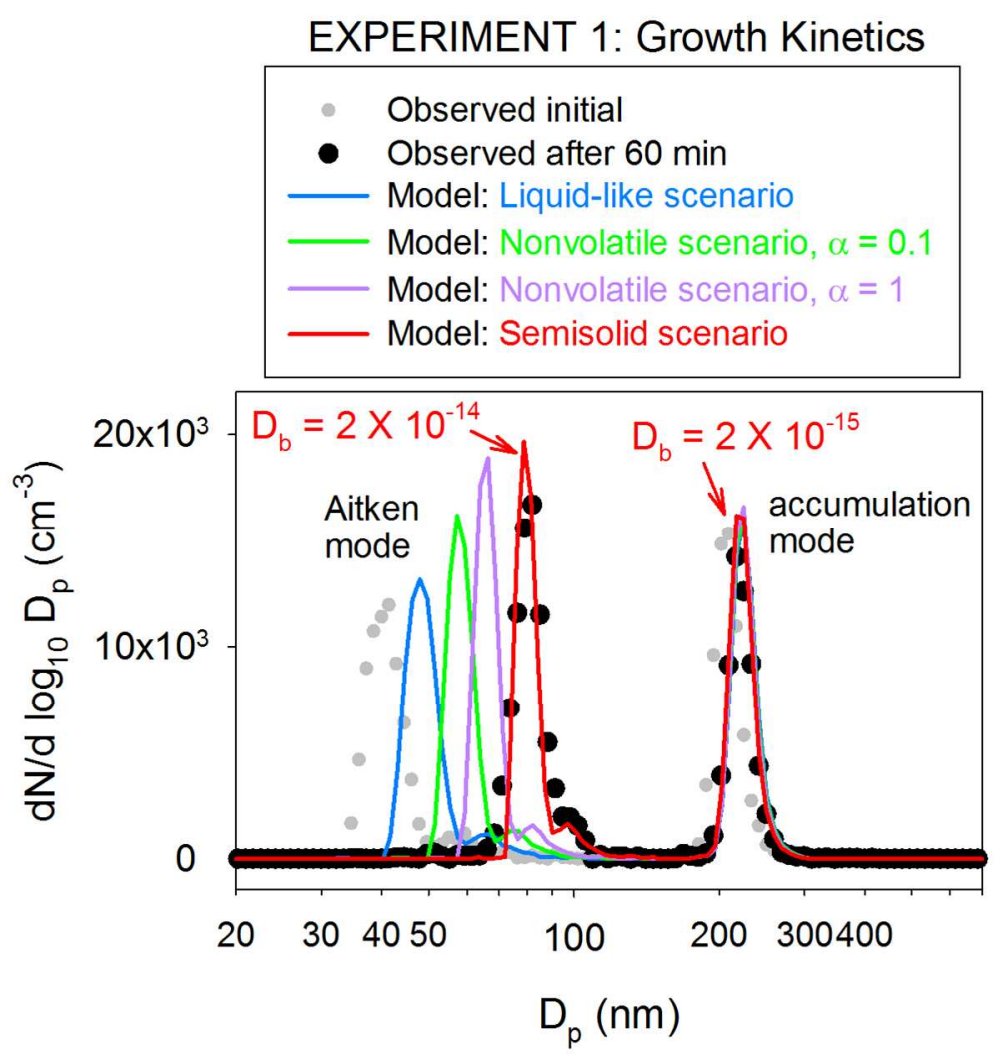

Figure 4. Comparison of the observed and predicted aerosol size distribution evolution due to isoprene SOA formation during Stage 2 of Experiment 1. Gray dots represent the observed initial bimodal aerosol size distributions consisting of Aitken mode ammonium sulfate particles and accumulation mode isoprene SOA. Black dots represent the observed size distribution after growth due to additional isoprene SOA formation. The lines represent model predictions for different scenarios. The liquid-like scenario (with $D_{b}>10^{-10} \mathrm{~cm}^{2} \mathrm{~s}^{-1}$ ), which assumes rapid diffusion of the condensing organic molecules inside the particle phase-similar to instantaneous equilibrium gas-particle partitioning - and grossly under predicts the growth of the Aitken mode. Even the nonvolatile vapor condensation scenarios, with mass accommodation coefficient $\alpha=0.1$ and 1 , fail to explain the growth of the Aitken mode. The semisolid scenario successfully reproduces the growth of both the Aitken and accumulation modes, with the required $D_{b}$ values as indicated in the plot. 


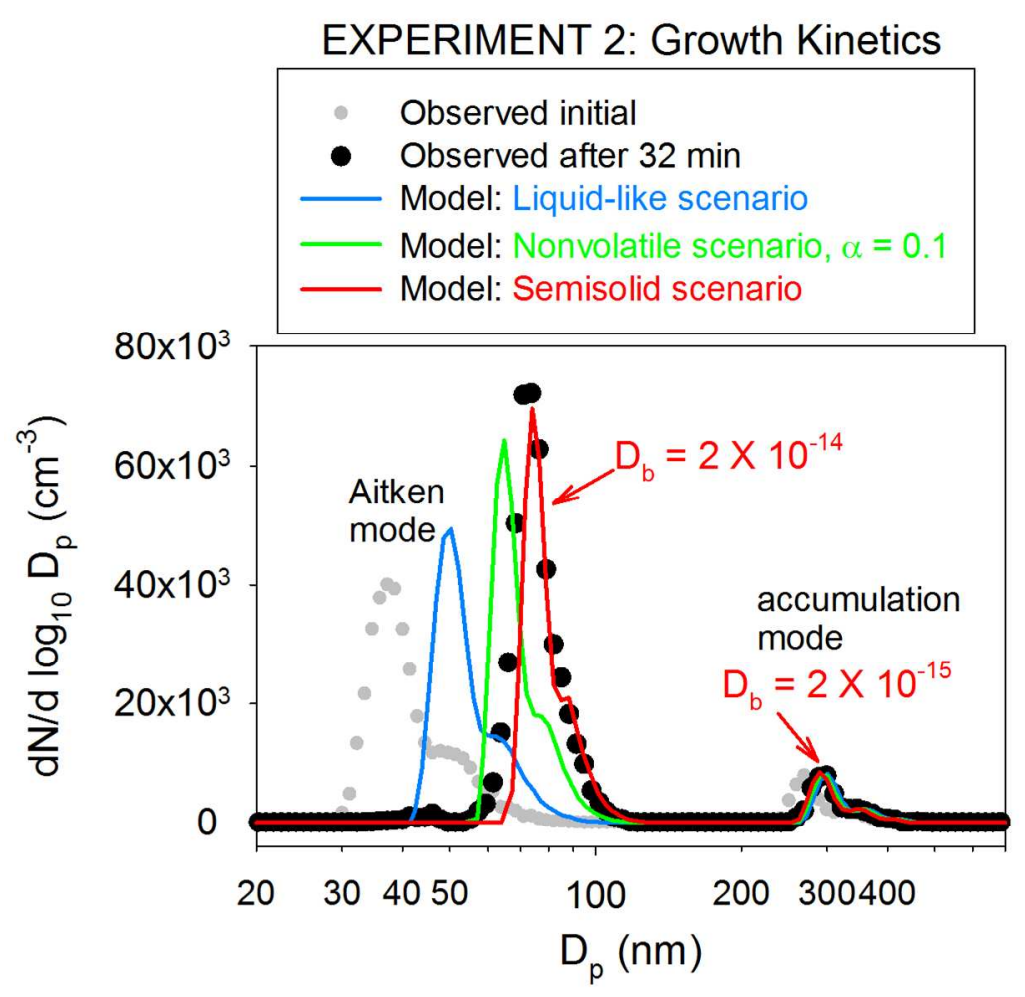

411

412

413

414

415

416

417

418

419

420

421

422

Figure 5. Comparison of the observed and predicted aerosol size distribution evolution due to isoprene SOA formation during Stage 2 of Experiment 2. Gray dots represent the observed initial bimodal aerosol size distributions consisting of Aitken mode ammonium sulfate particles and accumulation mode $\alpha$-pinene SOA. Black dots represent the observed size distribution after growth due to additional isoprene SOA formation. The lines represent model predictions for different scenarios. The liquid-like $\left(D_{b}>10^{-10} \mathrm{~cm}^{2} \mathrm{~s}^{-1}\right)$ and nonvolatile $(\alpha=0.1)$ scenarios underpredict the growth of the Aitken mode while the semisolid scenario successfully reproduces the growth of both the Aitken and accumulation modes, with the required $D_{b}$ values as indicated in the plot. 


\section{ASSOCIATED CONTENT}

424 Supporting Information. Detailed information on mass spectrometers and box models.

425 Summary of aerosol growth experiments (Table S1). Time evolution of key variables in aerosol

426 growth experiments (Figures S2 and S3). Evaporation profiles of total particle and individual

427 compounds (Figure S4). Sensitivity of growth kinetics to the prescribed bulk diffusivity values

428 for the Aitken and accumulation modes in aerosol growth experiments (Figures S5 and S6).

429 AUTHOR INFORMATION

430 Corresponding Author

431 *Phone: 206-528-3215; email: rahul.zaveri@pnnl.gov

432 Present Addresses

433 §aboratory of Atmospheric Chemistry, Paul Scherrer Institute, 5232 Villigen-PSI, Switzerland

$434{ }^{\dagger}$ Rosenstiel School of Marine \& Atmospheric Science, University of Miami, Miami, FL 33149, 435 USA

$436{ }^{\ddagger}$ Department of Chemistry, Purdue University, West Lafayette, IN 47907, USA

$437 \quad$ Notes

438 The authors declare no competing financial interest

\section{ACKNOWLEDGMENTS}

440 This research was supported by the Office of Science of the U.S. Department of Energy (DOE) as

441 part of the Atmospheric System Research program and by the Environmental Molecular

442 Sciences Laboratory, a national scientific user facility sponsored by the DOE's Office of

443 Biological and Environmental Research at Pacific Northwest National Laboratory (PNNL). PNNL 
444

445

446

447

448

449

450

451

452

453

454

455

456

457

458

459

460

461

462

463

464

465

466

467

468

469

470

471

472

473

474

475

476

477

478

479

is operated for DOE by Battelle Memorial Institute under contract DE-AC05-76RL01830. Data

used in this work are available from the corresponding author (rahul.zaveri@pnnl.gov).

\section{REFERENCES}

(1) Zhang, Q.; Jimenez, J. L.; Canagaratna, M. R.; Allan, J. D.; Coe, H.; Ulbrich, I.; Alfarra, M. R.; Takami, A.; Middlebrook, A. M.; Sun, Y. L.; Dzepina, K.; Dunlea, E.; Docherty, K.; De-Carlo, P. F.; Salcedo, D.; Onasch, T.; Jayne, J. T.; Miyoshi, T.; Shimono, A.; Hatakeyama, S.;

Takegawa, N.; Kondo, Y.; Schneider, J.; Drewnick, F.; Borrmann, S.; Weimer, S.; Demerjian, K.; Williams, P.; Bower, K.; Bahreini, R.; Cottrell, L.; Griffin, R. J.; Rautiainen, J.; Sun, J. Y.; Zhang, Y. M.; Worsnop, D. R. Ubiquity and dominance of oxygenated species in organic aerosols in anthropogenically-influenced Northern Hemisphere mid-latitudes. Geophys. Res. Lett. 2007, 34, L13801.

(2) Pierce, J. R.; Leaitch, W. R.; Liggio, J.; Westervelt, D. M.; Wainwright, C. D.; Abbatt, J. P. D.; Ahlm, L.; Al-Basheer, W.; Cziczo, D. J.; Hayden, K. L.; Lee, A. K. Y.; Li, S.-M.; Russell, L. M.; Sjostedt, S. J.; Strawbridge, K. B.; Travis, M.; Vlasenko, A.; Wentzell, J. J. B.; Wiebe, H. A.; Wong, J. P. S.; Macdonald, A. M. Nucleation and condensational growth to CCN sizes during a sustained pristine biogenic SOA event in a forested mountain valley. Atmos. Chem. Phys. 2012, 12, 3147-3163.

(3) Riipinen, I.; Pierce, J. R.; Yli-Juuti, T.; Nieminen, T.; Häkkinen, S.; Ehn, M.; Junninen, H.; Lehtipalo, K.; Petäjä, T.; Slowik, J.; Chang, R.; Shantz, N. C.; Abbatt, J.; Leaitch, W. R.; Kerminen, V.-M.; Worsnop, D. R.; Pandis, S. N.; Donahue, N. M.; Kulmala, M. Organic condensation: a vital link connecting aerosol formation to cloud condensation nuclei (CCN) concentrations. Atmos. Chem. Phys. 2011, 11, 3865-3878.

(4) Riipinen, I.; Yli-Juuti, T.; Pierce, J. R.; Petäjä , T.; Worsnop, D. R.; Kulmala, M.; Donahue, N. $M$. The contribution of organics to atmospheric nanoparticle growth. Nature Geoscience 2012, 5, 453-458.

(5) Jokinen, T.; Berndt, T.; Makkonen, R.; Kerminen, V.-M.; Junninen, H.; Paasonen, P.; Startmann, F.; Herrmann, H.; Guenther, A.; Worsnop, D. R.; Kulmala, M.; Ehn, M.; Sipilä, M. Production of extremely low-volatile organic compounds from biogenic emissions: measured yields and atmospheric implications. Proc. Natl. Acad. Sci. USA 2015, 112, 7123-7128.

(6) Zhang, Xi; Pandis, S. N.; Seinfeld, J. H. Diffusion-limited versus quasi-equilibrium aerosol growth. Aerosol Sci. Technol. 2012, 46, 874-885.

(7) Pankow, J. F. An absorption model of gas/particle partitioning of organic compounds in the atmosphere. Atmos. Environ. 1994, 28, 185-188.

(8) Tsigaridis, K.; Daskalakis, N.; Kanakidou, M.; Adams, P. J.; Artaxo, P.; Bahadur, R.; Balkanski, Y.; Bauer, S. E.; Bellouin, N.; Benedetti, A.; Bergman, T.; Berntsen, T. K.; Beukes, 
J. P.; Bian, H.; Carslaw, K. S.; Chin, M.; Curci, G.; Diehl, T.; Easter, R. C.; Ghan, S. J.; Gong, S. L.; Hodzic, A.; Hoyle, C. R.; Iversen, T.; Jathar, S.; Jimenez, J. L.; Kaiser, J. W.; Kirkevåg, A.; Koch, D.; Kokkola, H.; Lee, Y. H.; Lin, G.; Liu, X.; Luo, G.; Ma, X.; Mann, G. W.; Mihalopoulos, N.; Morcrette, J.-J.; Müller, J.-F.; Myhre, G.; Myriokefalitakis, S.; Ng, N. L.; O'Donnell, D.; Penner, J. E.; Pozzoli, L.; Pringle, K. J.; Russell, L. M.; Schulz, M.; Sciare, J.; Seland, $\varnothing$.; Shindell, D. T.; Sillman, S.; Skeie, R. B.; Spracklen, D.; Stavrakou, T.; Steenrod, S. D.; Takemura, T.; Tiitta, P.; Tilmes, S.; Tost, H.; van Noije, T.; van Zyl, P. G.; von Salzen, K.; Yu, F.; Wang, Z.; Wang, Z.; Zaveri, R. A.; Zhang, H.; Zhang, K.; Zhang, Q.; Zhang, X. The AeroCom evaluation and intercomparison of organic aerosol in global models. Atmos. Chem. Phys. 2014, 14, 10,845-10,895.

(9) Scott, C. E.; Spracklen, D. V.; Pierce, J. R.; Riipinen, I.; D'Andrea, S. D.; Rap, A.; Carslaw, K. S.; Forster, P. M.; Artaxo, P.; Kulmala, M.; Rizzo, L. V.; Swietlicki, E.; Mann, G. W.; Pringle, K. J. Impact of gas-to-particle partitioning approaches on the simulated radiative effects of biogenic secondary organic aerosol. Atmos. Chem. Phys. 2015, 15, 12,989-13,001.

(10) Shrivastava, M.; Cappa, C. D.; Fan, J.; Goldstein, A. H.; Guenther, A. B.; Jimenez, J. L.; Kuang, C.; Laskin, A.; Martin, S. T.; Ng, N. L.; Petäjä, T.; Pierce, J. R.; Rasch, P. J.; Roldin, P.; Seinfeld, J. H.; Shilling, J.; Smith, J. N.; Thornton, J. A.; Volkamer, R.; Wang, J.; Worsnop, D. R.; Zaveri, R. A.; Zelenyuk, A.; Zhang Q. Recent advances in understanding secondary organic aerosol: Implications for global climate forcing, Rev. Geophys. 2017, 55, 509-559.

(11) Ziemann, P. J.; Atkinson, R. Kinetics, products, and mechanisms of secondary organic aerosol formation. Chem. Soc. Rev. 2012, 41, 6582-6605.

(12) Shiraiwa, M.; Yee, L. D.; Schilling, K. A.; Loza, C. L.; Craven, J. S.; Zuend, A.; Ziemann, P. J.; Seinfeld, J. H. Size distribution dynamics reveal particle-phase chemistry in organic aerosol formation. Proc. Natl. Acad. Sci. USA 2013, 110 (29), 11,746-11,750.

(13) Kuwata, M; Martin, S. T. Particle size distributions following condensational growth in continuous flow aerosol reactors as derived from residence time distributions: Theoretical development and application to secondary organic aerosol. Aerosol Sci. Technol. 2012, 46, 937-949.

(14) Zaveri, R. A.; Easter, R. C.; Shilling, J. E.; Seinfeld, J. H. Modeling kinetic partitioning of secondary organic aerosol and size distribution dynamics: representing effects of volatility, phase state, and particle-phase reaction. Atmos. Chem. Phys. 2014, 14, 51535181.

(15) Kalberer, M.; Paulsen, D.; Sax, M.; Steinbacher, M.; Dommen, J.; Prevot, A. S. H.; Fisseha, R.; Weingartner, E.; Frankevich, V.; Zenobi, R.; Baltensperger, U. Identification of polymers as major components of atmospheric organic aerosols. Science 2004, 303, 1659-1662.

(16) Tolocka, M. P.; Jang, M.; Ginter, J. M.; Cox, F. J.; Kamens, R. M.; Johnston, M. V. Formation of oligomers in secondary organic aerosol. Environ. Sci. Technol. 2004, 38, 1428-1434. 
(17) Heaton, K. J.; Dreyfus, M. A.; Shenyi, W.; Johnston, M. V. Oligomers in the early stage of biogenic secondary organic aerosol formation and growth. Environ. Sci. Technol. 2007, 41, 6129-6136.

(18) Nguyen, T. B.; Laskin, J.; Laskin A.; Nizkorodov, S. A. Nitrogen-containing organic compounds and oligomers in secondary organic aerosol formed by photooxidation of isoprene. Environ. Sci. Technol. 2011, 45 (16), 6908-6918.

(19) Kidd, C.; Perraud, V.; Wingen, L. M; Finlayson-Pitts, B. J. Integrating phase and composition of secondary organic aerosol from the ozonolysis of $\alpha$-pinene. Proc. Natl. Acad. Sci. USA 2014, 111 (21), 7552-7557.

(20) Hawkins, L. N.; Baril, M. J.; Sedehi, N.; Galloway, M. M.; De Haan, D. O.; Schill, G. P.; Tolbert, M. A. Formation of semisolid, oligomerized aqueous SOA: Lab simulations of cloud processing. Environ. Sci. Technol. 2014, 48, 2273-2280.

(21) Virtanen, A.; Joutsensaari, J.; Koop, T.; Kannosto, J.; Yli-Pirilä, P.; Leskinen, J.; Mäkelä, J. M.; Holopainen, J. K.; Pöschl, U.; Kulmala, M.; Worsnop, D. R.; Laaksonen, A. An amorphous solid state of biogenic secondary organic aerosol particles. Nature 2010, 467, 824-827.

(22) Saukko, E.; Lambe, A. T.; Massoli, P.; Koop, T.; Wright, J. P.; Croasdale, D. R.; Pedernera, D. A.; Onasch, T. B.; Laaksonen, A.; Davidovits, P.; Worsnop, D. R.; Virtanen, A. Humiditydependent phase state of SOA particles from biogenic and anthropogenic precursors. Atmos. Chem. Phys. 2012, 12, 7517-7529.

(23) Renbaum-Wolff, L.; Grayson, J. W.; Bateman, A. P.; Kuwata, M.; Sellier, M.; Murray, B. J.; Shilling, J. E.; Martin, S. T.; Bertram, A. K. Viscosity of $\alpha$-pinene secondary organic material and implications for particle growth and reactivity. Proc. Nat. Acad. Sci. USA 2013, 110 (20), 8014-8019.

(24) Bateman, A. P.; Bertram, A. K.; Martin, S. T. Hygroscopic influence on the semisolid-toliquid transition of secondary organic materials. J. Phys. Chem. A 2015, 119, (19), 43864395.

(25) Song, M.; Liu, P. F.; Hanna, S. J.; Martin, S. T.; Bertram, A. K. Relative humidity-dependent viscosities of isoprene-derived secondary organic material and atmospheric implications for isoprene-dominant forests. Atmos. Chem. Phys. 2015, 15, 5145-5159.

(26) Song, M.; Liu, P. F.; Hanna, S. J.; Zaveri, R. A.; Potter, K.; You. Y.; Martin, S. T.; Bertram, A. $K$. Relative humidity-dependent viscosity of secondary organic material from toluene photo-oxidation and possible implications for organic particulate matter over megacities. Atmos. Chem. Phys. 2016, 16, 8817-8830.

(27) Bateman, A. P.; Gong, Z.; Liu, P.; Sato, B.; Cirino, G.; Zhang, Y.; Artaxo, P.; Bertram, A. K.; Manzi, A. O.; Rizzo, L. V.; Souza, R. A. F.; Zaveri, R. A.; Martin, S. C. Sub-micrometre particulate matter is primarily in liquid form over Amazon rainforest. Nature Geoscience 2016, 9, 34-37. 
(28) Vaden, T. D.; Imre, D.; Beránek, J.; Shrivastava, M.; Zelenyuk, A. Evaporation kinetics and phase of laboratory and ambient secondary organic aerosol. Proc. Nat. Acad. Sci. USA 2011, 108 (6), 2190-2195.

(29) Cappa, C. D.; Wilson, K. R. Evolution of organic aerosol mass spectra upon heating: implications for OA phase and partitioning behavior. Atmos. Chem. Phys. 2011, 11, 18951911.

(30) Abramson, E.; Imre, D.; Beránek, J.; Wilson, J.; Zelenyuk, A. Experimental determination of chemical diffusion within secondary organic aerosol particles. Phys. Chem. Chem. Phys. 2013, 15 (8), 2983-2991.

(31) Zhao, Y.; Wingen, L. M.; Perraud, V.; Finlayson-Pitts, B. J. Phase, composition, and growth mechanism for secondary organic aerosol from the ozonolysis of $\alpha$-cedrene. Atmos. Chem. Phys. 2016, 16, 3245-3264.

(32) Shiraiwa, M.; Seinfeld, J. H. Equilibration timescale of atmospheric secondary organic aerosol partitioning. Geophys. Res. Lett. 2012, 39, L24801.

(33) Shiraiwa, M.; Zuend, A.; Bertram, A. K.; Seinfeld, J. H. Gas-particle partitioning of atmospheric aerosols: interplay of physical state, non-ideal mixing and morphology. Phys.Chem. Chem. Phys. 2013, 15, 11441-11453.

(34) Shiraiwa. M.; Ammann, M.; Koop, T.; Pöschl, U. Gas uptake and chemical aging of semisolid organic aerosol particles. Proc. Natl. Acad. Sci. USA 2011, 108 (27), 1100311008.

(35) Kuwata, M.; Martin, S. T. Phase of atmospheric secondary organic material affects its reactivity. Proc. Natl. Acad. Sci. USA 2012, 109, 17354-17359.

(36) Li, Y. J.; Liu, P.; Gong, Z.; Wang, Y.; Bateman, A. P.; Bergoend, C.; Bertram, A. K.; Martin, S. $\mathrm{T}$. Chemical reactivity and liquid/nonliquid states of secondary organic material. Environ. Sci. Technol. 2015, 49 (22), 13264-13274.

(37) Bell, D. M.; Imre, D.; Martin, S. T; Zelenyuk, A. The properties and behavior of $\alpha$-pinene secondary organic aerosol particles exposed to ammonia under dry conditions. Phys. Chem. Chem. Phys. 2017, 19, 6497-6507.

(38) Wilson, J.; Imre, D.; Beránek, J.; Shrivastava, M; Zelenyuk, A. Evaporation kinetics of laboratory-generated secondary organic aerosols at elevated relative humidity. Environ. Sci. Technol. 2015, 49 (1), 243-249.

(39) Liu, P.; Li, Y. J.; Wang, Y.; Gilles, M. K.; Zaveri, R. A.; Bertram, A. K.; Martin, S. T. Lability of secondary organic particulate matter. Proc. Natl. Acad. Sci. USA 2016, 113(45), 1264312648.

(40) Yli-Juuti, T.; Pajunoja, A.; Tikkanen, O.; Buchholz, A.; Faiola, C.; Väisänen, O.; Hao, L.; Kari, E.; Peräkylä, P.; Garmash, O.; Shiraiwa, M.; Ehn, M.; Lehtinen, K.; Virtanen, A. Factors controlling the evaporation of secondary organic aerosol from $\alpha$-pinene ozonolysis. Geophys. Res. Lett. 2017, 44, 2562-2570. 
(41) Ye, Q.; Robinson, E. S.; Ding, X.; Ye, P.; Sullivan, R. C.; Donahue, N. M. Mixing of secondary organic aerosols versus relative humidity. Proc. Natl. Acad. Sci. USA 2016, 113, 1264912654.

(42) Guenther, A. B.; Jiang, X.; Heald, C. L.; Sakulyanontvittaya, T.; Duhl, T.; Emmons, L. K.; Wang, X. The Model of Emissions of Gases and Aerosols from Nature version 2.1 (MEGAN2.1): an extended and updated framework for modeling biogenic emissions. Geosci. Model Dev. 2012, 5, 1471-1492.

(43) Liu, S.; Shilling, J. E.; Song, C.; Hiranuma, N.; Zaveri, R. A.; Russell, L. M. Hydrolysis of organonitrate functional groups in aerosol particles. Aerosol Sci. Technol. 2012, 46 (12), 1359-1369.

(44) Holmes, J. R.; O'Brien, R. J.; Crabtree, J. H.; Hecht, T. A.; Seinfeld, J. H. Measurement of ultraviolet radiation intensity in photochemical smog studies. Environ. Sci. Technol. 1973, 7, 519-523.

(45) Liu, J. M.; D’Ambro, E. L.; Lee, B. H.; Lopez-Hilfiker, F. D.; Zaveri R. A.; Rivera-Rios, J. C.; Keutsch, F. N.; lyer, S.; Kurten, T.; Zhang, Z. F.; Gold, A.; Surratt,J. D.; Shilling, J. E.; Thornton, J. A. Efficient isoprene secondary organic aerosol formation from a Non-IEPOX pathway. Environ. Sci. Technol. 2016, 50, 9872-9880.

(46) Lindinger, W.; Hansel, A.; Jordan, A. On-line monitoring of volatile organic compounds at pptv levels by means of proton-transfer-reaction mass spectrometry (PTR-MS) - Medical applications, food control and environmental research. Int. J. Mass Spectrom. 1998, 173 (3), 191-241.

(47) DeCarlo, P. F.; Kimmel, J. R.; Trimborn, A.; Northway, M. J.; Jayne, J. T.; Aiken, A. C.; Gonin, M.; Fuhrer, K.; Horvath, T.; Docherty, K. S.; Worsnop, D. R.; Jimenez, J. L. Field-Deployable, High-Resolution, Time-of-Flight Aerosol Mass Spectrometer. Anal. Chem. 2006, 78 (24), 8281-8289.

(48) Jayne, J. T.; Leard, D. C.; Zhang, X.; Davidovits, P.; Smith, K. A.; Kolb, C. E.; Worsnop, D. R. Development of an aerosol mass spectrometer for size and composition analysis of submicron particles. Aerosol Sci. Technol. 2000, 33 (1-2), 49-70.

(49) Allan, J. D.; Jimenez, J. L.; Williams, P. I.; Alfarra, M. R.; Bower, K. N.; Jayne, J. T.; Coe, H.; Worsnop, D. R. Quantitative sampling using an Aerodyne aerosol mass spectrometer 1. Techniques of data interpretation and error analysis. J. Geophys. Res. 2003, 108(D3), 4090.

(50) Lee, B. H.; Lopez-Hilfiker, F. D.; Mohr, C.; Kurten, T.; Worsnop, D. R.; Thornton, J. A. An iodide-adduct high-resolution time-of-flight chemical-ionization mass spectrometer: application to atmospheric inorganic and organic compounds. Environ. Sci. Technol. 2014, 48 (11), 6309-6317.

(51) Lopez-Hilfiker, F. D.; Mohr, C.; Ehn, M.; Rubach, F.; Kleist, E.; Wildt, J.; Mentel, Th. F.; Lutz, A.; Hallquist, M.; Worsnop, D.; Thornton, J. A. A novel method for online analysis of gas 
and particle composition: description and evaluation of a Filter Inlet for Gases and AEROsols (FIGAERO). Atmos. Meas. Tech. 2014, 7 (4), 983-1001.

(52) D’Ambro, E. L.; Lee, B. H.; Liu, J.; Shilling, J. E.; Gaston, C. J.; Lopez-Hilfiker, F. D.; Schoebesberger, S.; Zaveri, R. A.; Mohr, C.; Lutz, A.; Zhang, Z.; Gold, A.; Surratt, J. D.; Rivera-Rios, J. C.; Keutsch, F. N.; Thornton, J. A. Molecular composition and volatility of isoprene photochemical oxidation secondary organic aerosol under low- and high- $\mathrm{NO}_{\mathrm{x}}$ conditions. Atmos. Chem. Phys. 2017, 17, 159-174.

(53) Roach, P. J.; Laskin, J.; Laskin, A. Nanospray desorption electrospray ionization: an ambient method for liquid-extraction surface sampling in mass spectrometry. Analyst 2010, 135, 2233-2236.

(54) Roach, P. J.; Laskin, J.; Laskin, A. Molecular characterization of organic aerosols using nanospray-desorption/electrospray ionization-mass spectrometry. Anal. Chem. 2010, 82, 7979-7986.

(55) Zelenyuk, A.; Imre, D.; Wilson, J.; Zhang, Z.; Wang, J.; Mueller, K. Airborne single particle mass spectrometers (SPLAT II \& miniSPLAT) and new software for data visualization and analysis in a geo-spatial context. J. Am. Soc. Mass Spec. 2015, 26, 257-270.

(56) Zaveri, R. A.; Easter, R. C.; Fast, J. D.; Peters, L. K. Model for Simulating Aerosol Interactions and Chemistry (MOSAIC). J. Geophys. Res. 2008, 113, D13204.

(57) Krechmer, J. E.; Coggon, M. M.; Massoli, P.; Nguyen, T. B.; Crounse, J. D.; Hu, W. W.; Day, D. A.; Tyndall, G. S.; Henze, D. K.; Rivera-Rios, J. C.; Nowak, J. B.; Kimmel, J. R.; Mauldin, R. L.; Stark, H.; Jayne, J. T.; Sipila, M.; Junninen, H.; Clair, J. M. S.; Zhang, X.; Feiner, P. A.; Zhang, L.; Miller, D. O.; Brune, W. H.; Keutsch, F. N.; Wennberg, P. O.; Seinfeld, J. H.; Worsnop, D. R.; Jimenez, J. L.; Canagaratna, M. R. Formation of low volatility organic compounds and secondary organic aerosol from isoprene hydroxyhydroperoxide low-NO oxidation. Environ. Sci. Technol. 2015, 49, 10330-10339.

(58) Trump, E. R.; Donahue, N. M. Oligomer formation within secondary organic aerosols: equilibrium and dynamic considerations. Atmos. Chem. Phys. 2014, 14, 3691-3701.

(59) Lopez-Hilfiker, F. D.; Mohr, C.; Ehn, M.; Rubach, F.; Kleist, E.; Wildt, J.; Mentel, Th. F.; Carrasquillo, A. J.; Daumit, K. E.; Hunter, J. F.; Kroll, J. H.; Worsnop, D. R.; Thornton, J. A. Phase partitioning and volatility of secondary organic aerosol components formed from apinene ozonolysis and $\mathrm{OH}$ oxidation: the importance of accretion products and other low volatility compounds. Atmos. Chem. Phys. 2015, 15, 7765-7776.

(60) Lopez-Hilfiker, F. D.; Mohr, C.; D’Ambro, E. L.; Lutz, A.; Riedel, T. P.; Gaston, C. J.; Iyer, S.; Zhang, Z.; Gold, A.; Surratt, J. D.; Lee, B. H.; Kurten, T.; Hu, W. W.; Jimenez, J.; Hallquist, M.; Thornton, J. A. Molecular composition and volatility of organic aerosol in the Southeastern U.S.: Implications for IEPOX derived SOA. Environ. Sci. Technol. 2016, 50, 2200-2209. 
667 (61) Gaston, C. J.; Lopez-Hilfiker, F. D.; Whybrew, L. E.; Hadley, O.; McNair, F.; Gao, H.; Jaffe, D.

668

669

670

671

672

673 A.; Thornton, J. A. Online molecular characterization of fine particulate matter in Port Angeles, WA: Evidence for a major impact from residential wood smoke. Atmos. Environ. 2016, 138, 99-107.

(62) Shiraiwa, M.; Li, Y.; Tsimpidi, A. P.; Karydis, V. A.; Berkemeier, T.; Pandis, S. N.; Lelieveld, J.; Koop, T.; Poschl, U. Global distribution of particle phase state in atmospheric secondary organic aerosols. Nat. Commun. 2017, 8, 15002. 